\title{
KEBAYA DALAM ARENA KULTULRAL
}

\author{
Oleh Inva Sariyati *)
}

\begin{abstract}
Kebaya is part of Indonesian fashion undergone significant changes. Kebaya change not only in shape, but also the changes experienced of kebaya also occur in terms of function and value. Changes that happened can not be separated from the habitus of producers and consumers and capitals which dominate in an field. With that in mind Bourdieu can be seen how the kebaya in a society, placing it as art and how capital appreciation as wrestling in a field.
\end{abstract}

Key word: kebaya, habitus, field, capital

\section{INTISARI}

Kebaya adalah bagian fashion Indonesia yang mengalami perubahan yang signifikan. Kebaya berubah bukan hanya pada bentuknya saja, akan tetapi perubahan yang dialami kebaya juga terjadi dari segi fungsi dan nilainya. Perubahan yang dialaminya tidak dapat terlepas dari habitus produsen dan konsumennya dan modal-modal yang mendominasi dalam sebuah arena. Dengan pemikiran bourdieu dapat dilihat bagaimana kebaya dalam sebuah masyarakat, menempatkannya sebagai barang seni dan bagaimana apresiasinya sebagai modal yang bergulat dalam sebuah arena.

Kata kunci: kebaya, habitus, arena, modal

\section{PENDAHULUAN}

Fashion adalah sebuah produk masyarakat yang dapat mengenali erubahaan terluar dari kebudayaan, fashion bisa menjadi penanda jaman. Bagi Jennifer Craik ashion dapat mengenali perubahan terluar yang nampak dari budaya dan usia, panpun dan dimanapun seseorang akan mengekspresikan individualitasnya dalam hiasan dan keterbukaan untuk berubah la mengalami perubahan seperti kemidi putar, mengulang apa yang pernah ditampilakan pada masa lalau, akan tetapi tidak akan sama persis dengan apa yang dulu pernah ada (Junka, 2001) Salah satu bagian dari fashion Indonesia yang dapat dikenali sebagai pakaian nusantara adalah kebaya. Kebaya berasal dari bahasa Arab "Kaba" yang berarti pakaian dan diperkenalkan lewat bangsa Portugis ketika mereka mendarat di Asia Tenggara. Kata kebaya diartikan sebagai jenis pakaian (atasan) pertama kali dipakai oleh wanita Indonesia abad ke-15 atau ke-

* Oleh Inva Sariyati ( invasari@yahoo.com), Mahasiswa Pengkajian Seni Rupa Pascasarjana Institut Seni Indonesia Yogyakarta 
16.(Lombard,2000,156) Kebaya adalah blus panjang yang dikenakan diluar kain panjang, lengan bajunya berbentuk kuncup mawar dengan bagian pergelangan tangan tidak terlalu lebar.(Achjadi,1986,18) Panjang kebaya berkisar sekitar pinggul atas sampai dengan lutut, biasanya dibuat dengan bahan broklat, lurik, organdi, dan katun polos. Pemakaian kebaya pada jaman dulu selalu didampingi dengan beberapa piranti penunjang, seperti kemben, stagen, dan kain panjang atau jarik/tapih dan selendang. Untuk kalangan rakyat selendang digunakan sebagai pengikat keranjang atau untuk menggendong anak, sedangkan untuk wanita kalangan atas selendang hanya berfungsi sebagai hiasan. (Lombard, 2000, 158)

Pada masa lalu kebaya bukan hanya sebagai pakaian yang berfungsi sebagai penutup badan, akan tetapi kebaya memiliki makna yang lain. Kebaya dianggap sebagai simbol dari kepatuhan, kehalusan, dan tindak tanduk wanita yang harus serba lembut, paduan jarit yang dililitkan secara sempit membuat si pemakai tidak bebas dalam bergerak, sehingga wanita menjadi terkesan lemah gemulai. Potongannya yang sederhana juga menggambarkan kesederhanaan masyarakat. Kebaya bukan hanya milik wanita-wanita pribumi, namun wanita peranakan Cina dan Belanda juga tertarik mengenakannya. Kebaya wanita peranakan ini kemudian lebih dikenal dengan kebaya encim dan nyonya, dengan bentuk yang sedikit berbeda dengan kebaya Jawa.

Seiring dengan perubahan jaman, maka kebaya pun juga mengalami sebuah perubahan yang signifikan. Sebelum masa reformasi yang terjadi di Indonesia kebaya dianggap sebagai pakaian yang tidak fashion, dianggap sebagai pakaian yang mendukung orde lama. Dunia politik yang selalu mengedepankan keberpihakan terhadap seseorang yang berkuasa membuat pakaian tradisional menjadi dijauhi. Wanita-wanita yang bepihak pada masa kekuasaan Soeharto tidak lagi bersedia mengenakan pakaian tradisional karena pakaian tersebut identik dengan masa pemerintahan Soekarno. Hal ini dikarenakan pada masa pemerintahan Soekarno kebaya memiliki peranan penting bagi wanita Indonesia, kebaya menjadi identitas feminisme wanita Indonesia, yang melekat kuat pada citra kaum perempuan terdidik atau kaum aristrokat. Ketika pemerintahan berpindah ke tangan Soeharto maka penggunaan kebaya untuk pakaian harianpun menjadi tergeser. Disinilah kekuasaan pemerintahan Soeharto berperan dalam keberlangsungan kebaya. Kebaya dijadikan pakaian seragam bagi dharma wanita pada masa itu. Peraturan ini dinilai sebagai bentuk kontrol terhadap kaum wanita, kekangan terhadap kebebasan. Kebaya dengan potongan kutu baru adalah kebaya yang sering dikenakan oleh Tien Soeharto, sebagai agen yang berada pada habitus atas ia menjadi patokan bagi perempuan Indonesia, sehingga model potongan yang banyak ditemui pada masa ini adalah kebaya kutu baru. Kebaya pada masa Soeharto tidak banyak mengalami perubahan bentuk yang berarti, kebaya kemudian menjadi anti fashion. Kebaya menjadi sebuah pakaian yang monoton, bahkan dianggap sebagai pakaian yang kuno, kaku, formal dan kurang menarik bagi perempuan Indonesia, khususnya kaum muda. Kebaya hanya dikenakan oleh orang yang sudah tua, atau 
pada kesempatan tertentu seperti acara resmi, acara tradisi. Keberadaannya semakin tersingkir seiring berkembangnya fashion dunia yang mulai diikuti oleh wanita Indonesia.

Kebaya mengalami perubahan yang signifikan setelah era reformasi yang terjadi di Indonesia pada tahun 1998, dengan munculnya para desainer-desainer yang kemudian mengubah kebaya dari pakaian yang nonfasion menjadi fasion kembali, kebaya dihidupkan kembali dari mati surinya. Para desainer merancang kebaya gaya masa kini yang mulai disebut dengan kebaya pesta. Disebut dengan kebaya pesta kerena memang kebayakebaya pasca era reformasi biasanya dikenakan pada saat pesta. Untuk menjaga eksistensinya kebaya kemudian dimodifikasi dengan beragam keagungan modern. Kebaya bukan lagi menjadi sebuah pakaian tradisional yang sederhana yang wajib dikenakan setiap hari yang menujukan kepatuhan, kesantunan masyarakat indonesia, namun kebaya menjadi sebuah pakaian pesta yang glamour dan elegan. Perubahan yang dialami kebaya tidak bisa lebas dari apa yang disebut dengan Piere Bourdieu sebagai habitus, modal, dan arena yang membentuknya.

\section{PEMBAHASAN}

\section{Habitus}

Konsep habitus dalam pemikiran Bourdieu dimaksudkan sebagai alternatif bagi solusi yang ditawarkan subjektivisme dan reaksi terhadap filsafat tindakan ganjil ala strukturalisme yang mereduksi agen menjadi sekedar pengemban atau ekspresi bawah sadar. Habitus adalah logika permainan, rasa praktis yang mendorong agen-agen bertindak dan bereaksi dalam situasi-situasi spesifik dengan satu cara yang tidak selalu bisa dikalkulasi sebelumnya, dan bukan sekedar kepatuhan sadar pada aturan-aturan.

Habitus adalah sistem disposisi yang bertahan lama dan bisa dipindahkan, struktur yang distrukurkan yang diasumsikan berdasarkan fungsi sebagai penstruktur struktur-struktur yaitu sebagai prinsip-prinsip yang melahirkan dan mengorganisasikan praktik-praktik dan representasi yang bisa diadaptasikan secara obyektif kepada hasil-hasilnya tanpa mengandaikan suatu upaya sadar untuk mencai tujuan tertentu. (Bourdie:2010:xv) Habitus ada didalam pikiran agen, lingkungan ada diluar pikiran mereka. Konsep habitus (kebiasaan) adalah struktur mental atau kognitif yang digunakan agen untuk menghadapi kehidupan social. Habitus adalah produk dari sejarah yang dihasilkan oleh individu maupun kelompok yang menciptakan tindakan individu maupun kelompok sesuai dengan pola yang dihasilkan sejarah.

Sebagai pakaian harian dan seragam bagi dharma wanita kebaya tampil dengan kesan sederhana. Bahan yang digunakan biasanya cenderung dari bahan katun untuk harian di kalangan masyarakat kelas bawah, budru dan sutra untuk wanita dari kalangan kelas menengah atas. Sebagai pakaian harian tidak ada aksesoris maupun aksen tambahan dalam kebaya. Sedangkan untuk seragam atau acara formal biasanya ditambahkan selendang dan peniti/ bros yang disematkan didada. 
Kemunculan para desainer ini memberi kehidupan baru pada kebaya. Reformasi memberi ruang bagi mereka untuk bebas berekspresi, sehingga para desainer bisa mengkreasikan bentuk kebaya yang tadinya dinilai kaku, kuno menjadi pakaian yang elegan. Sekarang ini kebaya hadir dengan vareasi yang bermaca m-macam, ada yang menampilkan kebaya dengan potongan yang sangat berbeda baik dari segi potongan garis leher, potongan bawahan yang dibuat sangat panjang, lengan dengan berbagai bentuk, paduan kain pada bagian lengan yang dibentuk tertumpuk, dan lainnya. Ada pula yang tampil seperti kebaya masa lalu, namun diberi aksen yang sedikit berbeda karena fashion memang seperti kemidi putar, selalu mengulangi dan bervariasi dengan gaya dan model lama. Fashion selamanya akan kembali kurang lebih dalam bentuk yang sama persis, sehingga

"baru" tidak ada. Menjadi "baru" hanya sesaat saja dan kemudian akan hilang dan tidak mempunyai daya kekuatan yang memikat lagi. (Junka:2001) Ketika para perancang kebaya menciptakan bentuk kebaya dan memberi sentuhan baru, maka kebaya yang tadinya mati suri dan menjadi anti fashion kemudian berubah menjadi fashion kembali, karena kebaya sudah diskontinuitas, ada perubahan didalamnya.

Kedekatan para desainer ternama dengan kalangan borjuis menuntut mereka untuk selalu menyuguhkan fashion yang glamour, unik, elegan. Kebaya tidak hanya untuk acara formal, pesta, ataupun pernikahan, kebaya kadang kala juga didesain untuk perlehatan akbar di panggung hiburan. Fashion barat yang dianut oleh para konsumen memberikan dampak pada potongan kebaya. Jika dahulu kebaya cenderung tertutup, maka kebaya yang ditampilkan para desainer sekarang terkadang ditampilkan dalam potongan yang terbuka dan lebih berani dalam eksplorasi bentuk. Eksplorasi tidak hanya terjadi dalam bentuk potongan kebaya, bahan material dan aksesoris penunjang kebayapun juga dieksplor sedemikian rupa untuk menciptakan kebaya masa kini. Kebaya masa lalu dibuat dari bahan seperti bludru, katun, sutra, kini kebaya bisa dibuat dari satin, lace, atau kain yang terbuat dari serat nanas, serat pisang yang dipadukan dengan kristal, logam atau manik-maik. Keberadaan kaum hedonis memang sangat berpengaruh terhadap perkembangan fashion kebaya di Indonesia. Tuntutan yang mereka berikan pada para desainer membuat kreasi kebaya semakin beragam.

Selain dipengaruhi oleh fashion barat, fashion indonesia juga dipengaruhi oleh fashion muslim yang sekarang ini sedang menjadi trend. Selain mempengaruhi fashion indonesia secara umum, kebaradaan fashion muslim ini juga berdampak pada desain kebaya. Untuk memenuhi kebutuhan fashion yang syar'i maka para desainer juga menciptakan kebaya yang cenderung tertutup seperti dengan desain kerah tegak yang menutupi seluruh leher, mengkombinasikan broklat atau tile bordir dengan bahan yang lebih tertutup, sehingga kulit sipepakai tidak akan terlihat.

Para desainer ini dalam 
pemikiran Bourdieu kemudian disebut dengan agen, para agen ini memiliki habitus yang berbeda namun hampir sama, jadi wajar saja jika dalam dunia mode kebaya banyak karya-karya mereka yang mempunyai kemiripan. Hal ini senada dengan apa yang dipikirkan oleh simmle bahwa kecenderungan fashion itu ada dua, yakni kebutuhan untuk menyatu dan kebutuhan untuk terisolasi tidak dapat berdiri sendiri, bila salah satu daya tersebut lenyap maka tidak pernah ada fashion. Desainer yang satu akan meniru desainer yang lain tapi selalu ada yang membedakan dalam setiap rancangannya.

Habitus individu dipengaruhi oleh posisi habitus dalam sebuah arena. Anne avanti dan desainer terkenal lainnya berada pada habitus teratas dalam arena produksi kultural dan ekonomi dalam perkembangan kebaya saat ini, sehingga mereka kemudian diikuti oleh habitus dibawahnya. Para produsen kebaya masal mengikuti apa yang dihasilkan oleh desainer-desainer itu. Untuk menciptakan kebaya yang serupa, mereka para produsen ini dibantu oleh media baik cetak maupun digital. Kebaya yang mereka hasilkan tidaklah seglamour kebaya desainer ternama tersebut. Potongan yang lebih sederhana atau penggunaan bahan yang lebih rendah biasanya dipilih untuk memenuhi kebutuhan meniru tersebut. Jika para desainer menghadapi tuntutan dari kelas menengah keatas, maka para produsen masal ini menjawab permintaan pasar kelas bawah. Habitus dari agen-agen yang

berasal dari kelas sosial atas biasanya akan diikuti oleh agen-agen lain yang baik yang berasal dari kelas yang sama maupun dari kelas sosial yang Ibih rendah, baik itu dari produsen karya maupun konsumennya.

\section{Agen}

1. Desain

Para desainer adalah agen yang memproduksi kebaya dalam dunia fashion di Indonesia. Anne Avantie, Dhea Panggabean, Amy Atmanto, Edward Hutabarat merupakan beberapa desainer yang berkontribusi dalam perkembangan kebaya di Indonesia. Diantara para desainer tersebut, nama Anne Avantie sebagai desainer kebaya yang lebih menonjol dibanding lainnya. Anne Avantie bahkan mendapat gelar sebagai pelopor kebaya kontemporer karena konsistensinya dalam bidang kebaya. la telah berkecimpung dalam dunia mode indonesia selama 25 tahun, dan karyakarya hasil rancangannya telah banyak dikenakan para wanita-wanita kelas atas.

\section{Agen pembawa fashion barat}

Salah satu artis yang menjadi agen yang mengkonsumsi kebaya yang terpengaruh fashion barat adalah Agnes Monika. Dalam beberapa kesempatan agnes tampil dengan balutan kebaya yang didesain dengan potongan lebih terbuka dibagian dada, kebaya yang ia kenakan dipadukan dengan kain panjang dengan belahan dari paha atas atau dipadukan dengan celana ketat sepaha. Selain Agnes banyak pula artis yang tampil dengan kebaya dengan potongan yang terbuka, hal ini diikuti pula oleh agen-agen lain baik yang berasal dari kelas sosial yang sama maupun yang lebih rendah. 


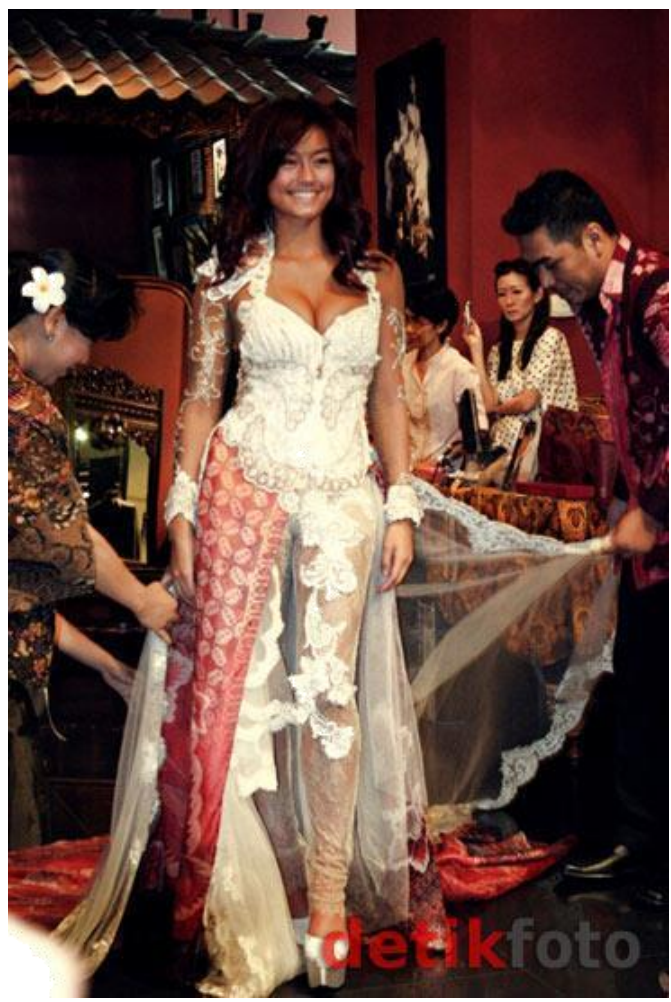

Gambar 1. Agnes Monika sebagai agen yang mengenakan kebaya yang dipengaruhi fashion barat

\section{Agen pembawa fashion muslim}

Kebedaan fashion muslim sebagai pakaian harian bagi wanita muslim berdampak pada fashion yang dikenakan wanita berhijab pada saat menghadiri acara resmi maupun pesta. Kebaya kemudian menyesuaikan kebutuhan para pemakainya yang ingin tampil secara syar'i. Beberapa artis seperti Marshanda, Oki Setiana Dewi, Adies Adelia tampil dengan balutan kebaya dan hijab pada saat pernikahan mereka. Kebaya yang didesain untuk para wanita berhijab ini jauh lebih tertutup. Sama seperti kebaya yang terpengaruh dengan budaya barat, kebaya dengan sentuhan Islampun juga diikuti oleh agen-agen lain yang berada pada kelas yang berbeda.

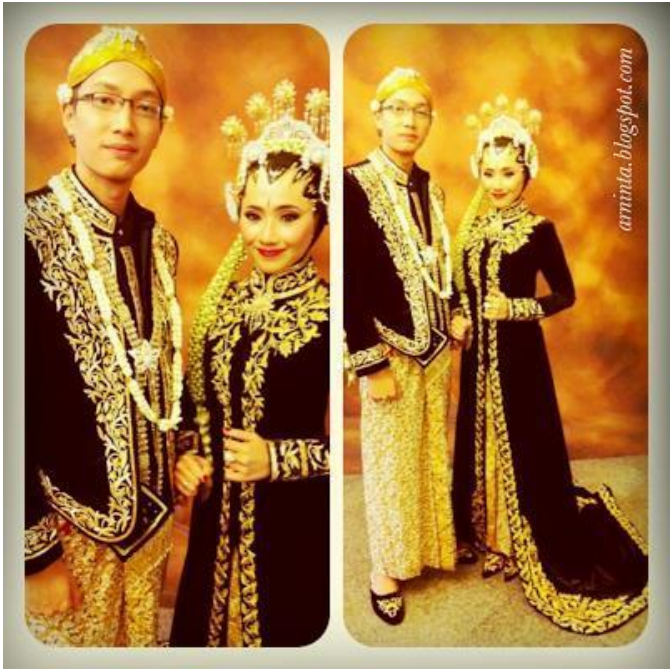

Gambar 2 . Salah satu agen yang mengenakan kebaya dengan terpengaruh fashion muslim

\section{Arena}

Habitus dari agen-agen yang berbeda tersebut kemudian bergulat dalam sebuah arena produksi kultural. Tentang arena Bourdieu menjelaskan bahwa arena adalah suatu konsep dinamis dimana perubahan posisi agen-agen mau tak mau menyebabkan peubahan struktur arena. Arena adalah analisis situs yang menetapkan bahwa setiap posisi didefinisikan secara subyektif oleh system property-properti distingtif yang melalui satu posisi diantara posisi-posisi lainnya. Arena seni adalah arena kekuatan dan juga arena pergulatan yang cenderung mengubah atau melanggengkan arena kekuatan ini. Arena menggambarkan struktur distribusi dan spesias kekuasaan modal yang pemilikannya memberikan akses pada keuntungan-keuntungan spesifik yang menjadi sasaran yang akan dicapai dalam arena tersebut (Bourdieu:1992:97). 
Posisi individu dalam arena ditentukan oleh penguasaan modal. Arena produksi kultural berada dalam arena kekuasaan karena lebih banyak memiliki bentuk-bentuk modal simbolis, tapi sekaligus berada dalam posisi terdominasi karena rendahnya tingkat modal ekonami yang dimilikinya. Arena produksi kultural distrukturkan dalam pengertian luas oleh oposisi dua sub arena yakni arena produksi terbatas dan arena produksi skala besar. (Bourdieu:2010:xxxiii)

Arena produksi terbatas menghasilkan produk seni demi seni itu sendiri atau seni tingkat tinggi (highbrow), arena produksi skala besar memproduksi seni populer atau massal (lowbrow). Arena produksi terbatas memproduksi barang seni untuk para produsen sendiri (seniman, museum, kurator dan kolektor), dan karena itu evaluasinya bersifat otonom, kriteria evaluasinya ditentukan oleh para seniman sendiri. Arena produksi skala besar memproduksi barang seni untuk para konsumen awam yang memiliki kemampuan untuk membelinya. arena produksi skala besar tidak otonom karena kriteria evaluasinya ditentukan oleh para konsumen yang kurang terdidik dalam dunia seni atau kaum awam (Purwanto: 2013: 238).

Berdasarkan sub arena produksi kultural tersebut maka bisa dikatakan bahwa para desainer dikatagorikan dalam arena produksi terbatas yang memiliki otonomi terhadap para desainer. Barang yang diproduksi desainer-desainer berupa kebaya dalam jumlah terbatas baik itu berupa kebaya artware maupun ready to ware. Dalam arena kultural kompetisi sering berkaitan dengan otoritas, otoritas yang berbasis prestis adalah simbolis dan bisa melahirkan kepemilikan atau peningkatan modal ekonomi.

Dengan menempatkan desainer pada konsep arena produksi terbatas ini maka harus ada penelusuran mengenai struktur agen-agen (desainer) dalam lingkaran ruang kebaya pasca reformasi yang berkembang di Indonesia khususnya di kalangan borjuis. Untuk menguraikan pergulatan agen-agen yang terjadi dalam arena ini tentunya tidak bisa dilepaskan dari modal simbolis dan modal kultural yang mereka miliki. Modal yang dimiliki oleh agen ini dipergunakan untuk memperebutkan kemampuan dalam mendesain dan pengakuan sosial hingga ada pembentukan trend dalam fashion kebaya.

Kehadiran desainer-desainer muda dalam dunia fashion juga menimbulkan interaksi dan pergulatan dalam arena ini. Pergulatan yang terjadi adalah sebuah alat untuk menunjukan kemampuan mendesain yang mereka miliki dan pengakuan atas profesionalitas dan karya mereka. Pengakuan ini menjadi penting karena sebuah karya seni baru bisa dikatakan eksis sebagai objek simbolis jika dia diakui dan dikenali, artinya jika dilembagakan secara sosial sebagai karya seni dan diterima oleh penikmat yang sanggup mengenali dan mau mengakuinya sebagai karya seni. (Bourdieu:2010:15)

Para produsen yang memproduksi kebaya dalam jumlah yang besar masuk dalam arena produksi skala besar. Dikarenakan tidak ada otomoni dalam arena ini, maka kekuatan pasarlah yang akan menentukan barang seni mana yang 
akan diproduksi. Desain kebaya yang diproduksi adalah adaptasi dari permintaan pasar, yakni dari jumlah konsumen yang membeli kebaya yang ada di pasar mode. Dalam hal ini arena berada dalam prinsip hierarki heteronom, dimana kesuksesan dapat diukur dari indeks penjualan.

Model kebaya modern yang diproduksi di pasaran pada tahun 2000-an adalah model kebaya ujung pendek datar, kebaya asimetris belah samping, kebaya ujung belah terbuka, kebaya sedang ujung terbuka, kebaya bulat ujung setengah terbuka, kebaya asimetris tumpuk, kebaya belah samping, serta kebaya bulat ujung terbuka. Sedangkan asesoris yang biasanya ditambakan pada kebaya modern adalah payet, bordir, batu-batuan.

Model kebaya pada tahun 2013 sampai sekarang dibuat menyerupai gaungaun pesta. Potongan kebaya yang panjang sampai menyentuh tanah, atau justru pendek yang kemudian dipadukan dengan rok yang mekar seperti fashion barat era 20an. Adapula kebaya untuk anak muda, yakni kebaya dengan potongan rempel pada pinggang, Penggunaan kain bludru juga kembali dilirik oleh pasar untuk menampilkan kejayaan kain ini pada masa lalu. Selain itu untuk menjawab keinginan pasar Indonesia saat ini dimana banyak konsumen yang mengenakan hijab maka kebaya pun dibuat lebih tertutup. Untuk aksesoris payet, bordiran dan juga betubatuan masih diminati oleh pasar, sepertinya mereka sudah menjadi bagian kebaya yang tidak terpisahkan.

\section{Modal}

Dalam arena produksi kultural ada dua modal yang sangat penting yakni modal simbolis dan modal kultural. Modal simbolis dijelaskan oleh Bourdieu sebagai modal yang mengacu pada derajat akumulasi prestise, ketersohoran, konsekrasi atau kehormatan dan dibangun diatas dialektika pengetahuan dan pengenalan. Sedangkan modal kultural menyoroti bentuk-bentuk pengetahuan kultural, kompotisi-kompotisi atau disposisi-disposisi tertentu. Modal kultural sebagai suatu bentuk bentuk pengetahuan, suatu kode internal atau suatu akusisi kognitif yang melengkapi agen sosial dengan empati terhadap apresiasi terhadap, atau kompetensi di dalam, pemilah-milahan relasi-relasi dan artefakartefak kultural. (Bourdieu:2010:xix)

Modal simbolik yang dimiliki oleh para agen seperti desainer ternama Anne Avantie, Edward Hutabarat, Amy Atmojo, Dhea Panggabean menjadi penentu keberlangsungan praktif kreatif. Dalam dunia fashion kebaya di Indonesia modal simbolis dari Anne Avanti lebih dominan dibandingkan dengan desainer lainnya, dengan modal yang ia miliki sudah banyak karya yang berhasil ia ciptakan selama 25 tahun dalam dunia mode. Banyak konsumen dari kalangan pejabat dan Selebritis yang mempercayakan penampilannya dengan kebaya ciptaan Anne.

Modal kultural yang dimiliki oleh para desainer juga menjadi bagian penting dalam arena kultural. Modal kultural yang dimiliki Anne dalam bidang pendidikan lebih rendah jika dibandingkan dengan Amy Atmojo yang menempuh pendidikan s1 dalam bidang ekonomi dan hukum dan juga khursus desain yang di tempuh di 
Sidney, karena Anne hanyalah tamatan SMA dan belajar desain secara otodidak. Namun kedua desainer ini memiliki kesamaan yakni mengenal dunia jahit sejak kecil dari ibu mereka.

Pengetahuan dan kecintaan pada kain-kain tradisi membawa Edward Hutabarat pada desain-desain kebaya yang lebih eksotik. Modal kultural yang dimiliki para desainer ini sebenarnya tidak begitu jauh berbeda. Pada hakekatnya ide untuk merancang kebaya dalam bentuk yang lebih glamour dan lebih segar berawal dari kesadaran dan kecintaan mereka akan busana tradisional yang telah dijadikan pakaian nasional. Keinginan untuk menjaga dan melestarikan kebaya mereka gunakan sebagai modal kultural dalam pertarungan di arena.

Selain modal simbolik dan kultural keberadaan kebaya sebagai fashion yang lebih tinggi juga di dukung oleh modal ekonomi. Para perancang yang mempunyai modal simbolik dan kultulral yang lebih dominan dari pada lainnya membuka beberapa rumah mode di kota-kota besar untuk menjaring konsumen. Ketertarikan konsumen untuk mengenakan kebaya hasil rancangan desainer ternama ini menjadikan kebaya menjadi bernilai ekonomi yang tinggi. Sedangkan mereka, para konsumen yang tidak mampu membeli kebaya hasil rancangan desainer akan membeli kebaya dari produsen kebaya masal dengan harga yang jauh lebih murah, dan nilai glamour yang lebih rendah. Mereka inilah yang akan menentukan pasar dan mempengaruhi indeks penjualan.

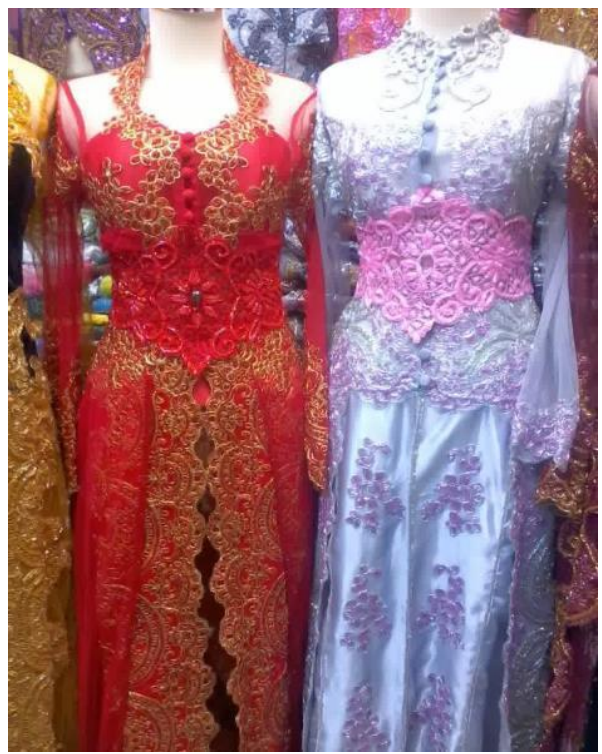

Gambar 3. Kebaya Bordir

Sumber:

http://ibotcollection.blogspot.com



Gambar 4. Kebaya Batik

Sumber:

https://www.pinterest.com/dandedibi/ann e-avantie

Gambar 3 merupakan kebaya yang diproduksi oleh produsen skala besar, yang dikonsumsi oleh kalangan menengah 
ke bawah yang biasa dijual di toko-toko secara grosir, sedangkan gambar 4 adalah kebaya hasil rancangan Anne Avantie yang diperagakan dalam fashion show 25 tahun masa karirnya di dunia mode. Keglamouran dan kesan elegan sangat nampak pada kebaya Anne ini, penggunaan bahan dan potongan kebaya tersebut menampilkan dari kelas manakah sang pemakai. Sedangkan untuk kebaya yang dijual di pasar grosir ini tidak terlalu menunjukan keglamoran.

\section{Kesimpulan}

Kebaya bukan hanya produk fashion yang yang mencerminkan pakaian nasional Indonesia. Akan tetapi kebaya dalam pergulatannya di dalam arena produksi kultural menunjukan dimana kelas yang ia duduki. Habitus dari agen dan modal-modal yang mereka miliki mengantarkan kebaya menjadi barang seni yang bernilai. Modal sosial yang dimiliki kebaya akhirnya mengalami perubahan seiring dengan desain, bahan, dan waktu pemakaian. Kebaya yang pada mulanya sempat menjadi kebanggaan wanita Indonesia, menjadi pakaian harian yang sederhana, hingga sempat nyaris kehilangan pesonakan, kemudian muncul kembali menjadi pakaian yang bernilai tinggi. Kebaya berubah menjadi sebuah simbol kemewahan, keglamouran dan keeleganan seorang wanita Indonesia. Melalui pemikiran Bourdie dapat dilihat bagaimana status sosial seseorang direproduksi melalui kebaya, dan bagaimana cita rasa seni individu dan masyarakat dapat mengubah kebaya.

\section{KEPUSTAKAAN}

Achjadi, Judi. 1986. Pakian Daerah Wanita Indonesia. Jakarta : Djambatan

Barnat, Malcolm. 2011. Fashion Sebagai Komunikasi Cara Mengkomunikasikan Identitas Sosial Sekssual Kelas Dan Gender. Yogyakarta: Jalasutra.

Bourdieu, Pierre and Loic J.D. Wacquant. 1992. An Invitation to Reflexive Sociology. Chicago: The University of Chicago Press.

Bourdieu, Pierre. 2012. Arena Produksi Kultural Sebuah Kajian Sosiologi Budaya, Kreasi Wacana.

Gronow, Jukka 2001. The Sociology Of Taste, Taylor And Francis E-Library.

Lombart, Denys. 2000. Nusa Jawa Silang

Budaya: Batas-Batas Pembaratan. Jakarta: Gramedia Pustaka Utama.

Lombart, Denys. 2000. Nusa Jawa Silang

Budaya: Jaringan Asia. Jakarta: Gramedia Pustaka Utama.

Purwanto, Antonius. 2013. Modal Sosial Dan Modal Budaya Dalam Seni Kerajinan Keramik, Jurnal Sosiologi Masyarakat Vol. 18, no. 2.

Triyanto, Bentuk Kebaya Pasca Reformasi. Tesis sebagai syarat untuk mencapai derajat Sarjana S-2 pada Program Studi Pengkajian Seni Pertunjukan dan Seni Rupa, Bidang Ilmu Multi Disiplin, Pascasarjana Universitas Gadjah Mada, Yogyakarta (2008) 